\title{
Populist Political Parties in the Media: A Newspaper Analysis of the PVV
}

\begin{abstract}
Since the turn of the twenty-first century, populism is on the rise in Europe. Traditionally, scholars focus on the definition of populism and the discovery of explanatory factors for the rise of populist parties. The role of the news media has largely been neglected here, even though studies outline that the media play a large role in shaping people's opinions. This study concentrates on how media content might affect public perceptions concerning populist parties. It undertakes a newspaper analysis of three Dutch newspapers, focusing on the Dutch Party for Freedom (PVV). The media-effect 'framing' is used as a helpful tool to make sense of the media content. The analysis shows that the selected newspapers create a largely negative environment for the PVV in Dutch politics. Furthermore, the media portrayal becomes increasingly negative over time as more extreme frames are used to address the party. In addition, the study finds that both popular and quality newspapers are rather negative towards populist parties.
\end{abstract}

Nicole Kusters ${ }^{1}$

\footnotetext{
${ }^{1}$ Nicole Kusters received a bachelor degree in European Studies at Maastricht University in 2017. At the moment she takes a Master in European Studies at Maastricht University. Contact: nicole.kusters@outlook.com
} 


\section{Introduction}

Since the turn of the twenty-first century, Europe has witnessed a substantial increase in the number and success of populist parties. In the last decade, a lot of these parties have not only managed to enter national parliaments and governments, but during the 2014 European Parliament elections they also made a big step forward. In France, the United Kingdom, Greece, Denmark, and Hungary the populists received the highest share of the votes (European Parliament, 2014). Populist parties differ amongst countries, but they all vow to return the 'sceptre of democracy' to the 'people' (Albertazzi \& McDonnell, 2008, p. 2).

Populism has attracted a lot of academic attention. On the one hand, the scholarly debate concentrates on describing what populism entails. Mudde (2004), Canovan (1999), and Taggart (2004) all present some conceptualisation by which they define populism. On the other hand, authors focus on discovering factors that can explain the rise and/or downfall of populist parties. Albertazzi \& McDonnell (2008) describe the rise of populism as a response to the failures of the traditional parties and as a product of a general political malaise characterised by decreasing turnouts (p. 1). It is remarkable, though, that only little attention is paid to the role the media play here. This becomes even more striking when considering Pels' (2011) argument that the media have become very important institutions in today's society which are able to shape and affect public opinion (p. 150). Blumler agrees that "any future attempt to analyse populism without taking into account [...] the media factor will be severely incomplete" (Boomgaarden \& Vliegenthart, 2007, p. 405). Therefore, this study is interested in the relationship between the media and populism.

The Netherlands presents an interesting case study because of the sudden rise of populist parties and the population's willingness to vote for them, but also because it used to be characterised as tolerant towards multiculturalism. Populism emerged rather late in this country compared to for instance France, Belgium, and Italy where it was already a prominent force (Pels, 2011, p. 15). At the start of the 2000s, the Netherlands witnessed the rise of the Lijst Pim Fortuyn (LPF) becoming the second largest party in the 2002 elections. The LPF's success was only short-lived, however, as a rapid demise followed after 2002 (Lucardie, 2008, pp. 151-153). Populism revived again in 2006 when Geert Wilders established his Partij voor de Vrijheid (PVV; i.e. Party for Freedom) and won nine seats during the parliamentary elections (p. 164). The PVV has vested its stronghold in Dutch politics with electoral victories in 2010 and 2017. Since the 2017 elections, it is the second largest party in Dutch parliament.

Lucardie (2008), Becker \& Cuperus (2010), and van Kessel (2011) examine the rise of the $P V V$ in the Netherlands. Its success is explained by de-pillarization, a focus of the press on the failures of the government, a growing insecurity concerning immigrants and multiculturalism, changes made to the welfare state, and rapid European integration. However, little research has been conducted regarding the relationship between news media and this party. Rooduijn (2013) finds that public debates in Dutch newspapers have become more populist in the 2000s. Moreover, Bosman \& d'Haenens 
(2008) investigate the framing of Pim Fortuyn in Dutch newspapers. There is a lack, though, of an in-depth investigation of how the PVV is framed.

This study researches the media portrayal of the $P V V$ to understand how the media play a role in national politics. It asks the following research question: How have the Dutch media portrayed the PVV over time? To answer this question, a newspaper analysis has been undertaken, concentrating on three Dutch newspapers with the aim of deriving frames from the examined articles. It is relevant to study the media since its content can influence how the public perceives of society (Pels, 2011, p. 150). The media can thus also affect the public's attitude towards populist parties. Regarding the academic contribution, this research bridges the gap between the role of the media concerning populist movements and the literature addressing media-effects. It not only provides a new angle from which to regard populist parties, but it also generates new knowledge about media content in general. In addition, the claim is that media frames have changed over time. Both quality and popular newspapers portray the PVV's success with increasingly negative frames. Just after its establishment, the newspapers were still surprised by the party's success. By 2010, it was framed as an anti-establishment party and a few years later this has developed into a radical right party frame. The newspapers argue that the PVV's success is caused by the population's dissatisfaction with the traditional political elite.

First, the existing literature is reviewed in order to provide conceptualisations of populism and the relationship between populism and the media. Second, the conceptual framework introduces the media-effect 'framing'. Next, the methodology is outlined, which describes the case selection and the methods for data collection and analysis. Subsequently, a content analysis is undertaken to study the newspapers. Frames are derived on the basis of three elements of Entman's (1993) definition of framing, namely problem definition, causal interpretation, and moral evaluation. Finally, it presents a discussion of the findings to observe whether there has been a change in media coverage.

\section{State of the art}

To demonstrate how this research fits into the broader scientific field, this part reviews scholarly literature that addresses populism and its respective relationship with the media. Canovan (1999) argues that populism presents a challenge to the established traditional political parties and their elite values. Populists claim to speak on behalf of the people and base their legitimacy on this idea (pp. 2-4). However, they cannot be acknowledged as 'true democrats' since "democracy as we know it is liberal democracy and [...] populism is dangerous because it is illiberal" (p. 7). Taggart (2004) takes a different approach than Canovan. He states that populism consists of five common features. First, it is hostile to representative politics. Second, populists tend to identify themselves with a heartland that represents an idealised version of their home country. Third, there is a lack of core values which explains why populists can range from ideologically left to right. Fourth, it is a response to some situation of extreme crisis. Fifth, populists have a self-limiting quality. They are reluctantly political and tend to disappear quickly from the political arena (pp. 273-276). Moreover, Mudde (2004) 
speaks of a populist Zeitgeist by which he means that "populist discourse has become mainstream in the politics of contemporary western democracies" ( $p$. 562). Populism is not a phenomenon of extreme crises. He further argues that populism entails that society is separated into two groups, "the 'pure people' versus 'the corrupt elite'", which are homogenous and antagonistic against each other. Moreover, politics should represent the general will of the people (p. 543).

Populists have a paradoxical relationship with the media. On the one hand, they are suspicious of the media since they perceive them as instruments of the established political elite (Canovan, 1999, p. 2). On the other hand, the increased role of the media in politics is one of the factors that has contributed to the rise of populist parties across Europe (Pasquino, 2008, p. 26). It is striking then that Mudde (2007) stresses that "the role of the media in the success and failure of populist [...] parties has received little serious attention [in existing literature]" (p. 248). Therefore, it is important to regard the academic work that covers the relationship between populism and the media.

Mazzoleni is one of the most prominent scholars in this field. He argues that the media are one of the factors providing support for populism's rise $(2003$, p. 6). He further elaborates that populist parties rely on the media since these "have contributed to a legitimisation of the issues, key-words and communication styles typical of populist leaders" (2008, p. 50). The media are central to the political process (p. 52) and politics has become mediatised shown by the personalisation of political leadership (p. 53). Other scholars also observe that the power of the media is an important requisite for the rise of populism. Pels (2011) acknowledges that the media can be both powerful allies of populist leaders and mobilise the public to support populist parties ( $p$. 160). Mudde (2007) stresses that high salience of their ideas in the media results in strong populist parties (p. 252). Specific country analyses demonstrate the relationship between the media and populism as well. Walgrave \& De Swert (2004) find that there exists a correlation between extreme right success and media coverage in Belgium (p. 495). In the Netherlands, Boomgaarden \& Vliegenthart (2007) discover that emphasising immigration-related issues in the media assists the success of anti-immigrant populist parties (p. 413). The media in Austria, especially the Kronen Zeitung, helped to spread the populist messages of Haider's FPÖ (Plasser \& Ulram, 2003, p 29).

This literature review shows that most authors mainly concentrate on what populism is and how the media contribute to the success and/or failure of populist parties. The media are a very prominent force in our everyday lives, which implies that they can also possibly affect the way in which citizens perceive populist parties. However, the large majority of the authors neglect how these parties are conceptualised in media content as they do not take into account the literature about media-effects. Therefore, the analysis extends the investigation into the field of media and populism by drawing on the media-effect 'framing'. This helps to understand how the media influence public perceptions of populism and thus how the media play a role in the rise of populist parties in national politics. The next part introduces what 'framing' entails and how it is used throughout the analysis. 


\section{Conceptual framework}

This part sets out a framework for understanding the media coverage of the $P V V$. It concentrates on one of the media-effects, namely framing. The next section introduces what framing is. Then, it is explained which elements a frame can consist of.

\subsection{Media-effects}

Lippmann already pointed out in 1922 that the news media help to construct public opinion (McCombs, 2004, p. 3). Our attitude towards populism and politics in general might thus also be influenced by their respective media coverage. Previous literature outlines three main effects that the media have on the public: agenda-setting, priming, and framing.

First, agenda-setting implies that the media have the "ability to influence the salience of topics on the public agenda" (McCombs, 2004, p. 1). This entails that there is a correlation between the subjects the media devote most attention to and the subjects the public finds most important to consider (Scheufele \& Tewksbury, 2007, p. 11). For instance, when the media extensively address environmental pollution as an important issue, individuals are likely to start thinking and talking about this issue themselves. Authors also acknowledge that television and newspapers play a part in setting the agenda for political issues (Herlé \& Rustema, 2012, p. 97). The second effect is priming which is often regarded as an extension of agenda-setting. It suggests that media coverage of some issues sometimes leads the public to evaluate for example political actors on the basis of these covered issues (Walgrave \& De Swert, 2004, p. 482).

The third effect, framing, is the one that this study focuses its attention on. It is different from agenda-setting and priming in that it does not concentrate on what issues the media presents, but it is interested in how these issues are presented and characterised (Semetko \& Valkenburg, 2000, p. 94). It assumes that public perceptions are always determined to some extent by how the news has framed them (Pels, 2011, p. 163). The concept of framing has its roots in the academic fields of psychology and sociology. Its psychological origins lie in the work of Kahneman \& Tversky (1979). They show how minor differences in the presentation of scenarios can lead to different public choices (Scheufele \& Tewksbury, 2007, p. 11). The leading scholar in the field is Entman (1993), who declares that to frame is "to select some aspects of a perceived reality and make them more salient in a communicating text, [...] to promote a particular problem definition, causal interpretation, moral evaluation, and/or treatment recommendation" (p. 52). Frames can stress different aspects of reality which leads audiences to have different perceptions ( $p$. 55). The media thus construct social and political reality. The public relies on how the media present news to them and framing "can systematically affect how recipients of the news come to understand [...] events" (Scheufele, 1999, p. 107).

This research assumes that the manner in which the media present news about populist parties shapes the public's perceptions. Therefore, it can eventually also influence the way in which people vote during parliamentary elections. However, it has to be acknowledged as well that the most profound limit to media-effects comes from the recipient. A person's pre-existing 
meaning structures, incorporating norms and values, limit the way in which media content can affect that person's perceptions (Scheufele, 1999, p. 105; Chong \& Druckman, 2007, p. 111).

\subsection{The four elements of a frame}

Even though a lot of work has been devoted to the definition of 'framing', there is still no systematic method of how to derive frames from media content. Matthes \& Kohring (2008) state that frames can be best understood as clusters of frame elements. Each frame is constructed by separate elements which are best observed via a content analysis (p. 263). This idea of a cluster of elements is visible in Entman's (1993) definition. He assumes that a frame consists of four separate elements. First, a problem definition which refers to the issues and actors by which the problem is discussed. Second, a causal interpretation which regards a specific outcome as either an attribution of success or of failure. Third, a moral evaluation which can be neutral, negative, or positive. Fourth, a treatment recommendation which appeals for or against a certain type of action that could be undertaken (p. 52; Matthes \& Kohring, 2008, p. 264).

The combination of Matthes \& Kohring's work and Entman's four elements presents a useful framework that helps to derive the frames from the newspaper articles. It makes it possible to consistently analyse the articles' content. It should be noted, however, that it is not necessarily the case that all four elements need to be present to derive a media frame. The next part explains how this framework is operationalised in the analysis.

\section{Methodology}

This part introduces the case selection, and the methods for data collection and analysis. Since it is rather difficult to observe meaningful frames in media coverage through a large- $\mathrm{N}$ study, this study conducts a qualitative research.

The previous part identified that frames consist of four separate elements: a problem definition, a causal interpretation, a moral evaluation, and a treatment recommendation. The analysis is guided by employing questions which are in correspondence with the first three elements. The treatment recommendation is disregarded since the analysis has indicated that newspapers only rarely provide certain advise as to what type of action the PVV should take or avoid. Table 1 shows the respective questions that are asked per element throughout the reading process.

Table 1: Framework for the analysis

\begin{tabular}{l|l|}
\hline Frame element & Question \\
\hline Problem definition & $\begin{array}{l}\text { What are the central problems that are defined } \\
\text { in the coverage of the PVV? }\end{array}$ \\
\hline Causal interpretation & $\begin{array}{l}\text { What causal interpretations are provided for the } \\
\text { success and/or failure of the PVV? }\end{array}$ \\
\hline Moral evaluation & Which terms are used to refer to the PVV?
\end{tabular}


The research adopts a method of analysis which is based on what Matthes \& Kohring (2008) describe as a 'hermeneutic approach'. Frames are identified "by providing an interpretative account of media texts linking up with broader cultural elements" (p. 259). This approach fits this study particularly well since it is concerned with an in-depth understanding of frames. Furthermore, the amount of collected data is rather small. As a consequence, the newspaper articles are thoroughly read and reviewed individually. The study further adopts an inductive approach to the analysis of the newspapers. That means that it "[analyses] a news story with an open view to attempt to reveal the array of possible frames" (Semetko \& Valkenburg, 2000, p. 94). This particular approach is taken because there are no established frames available to use as a guide as previous research is lacking in this field.

\subsection{The Netherlands as a case study}

The Netherlands has been chosen as a single case study to obtain an in-depth understanding of how the media frame populist parties. This country presents an interesting case. First, since it is remarkable that in a country that used to be characterised as very liberal and tolerant towards multiculturalism, radical right populism has been able to emerge so fast. Second, within a decade, two different populist parties managed to come particularly close to governing the country. Although the $L P F^{\prime}$ s success was short-lived, it was still a governing party in 2002. In 2010, the PVV received $15.5 \%$ of the votes and 24 seats after the parliamentary elections (van Kessel, 2011, pp. 73-75). From 2010 until 2012, the PVV was a so-called 'gedoogpartij' to the government. This means that the $P V V$ promised to support the reigning minority government in certain policy areas in order for them to have a majority in the Tweede Kamer (p. 85). Finally, since the Dutch electoral system has a very low electoral threshold, in contrast to for example Germany, voters can choose between a substantive amount of different political parties during parliamentary elections. It is interesting that in spite of this, the public still votes for populist parties.

\subsection{Newspaper selection}

Newspapers are chosen in this study as the means that represent the overall impact of the media on public perceptions. The Eurobarometer (2016) demonstrates that over two-thirds of the EU population reads the written press at least once a week (p. 12). This means that its content can substantially influence public opinion. In addition, to obtain and analyse television or radio content is fairly difficult since these are not as easily accessible as newspaper articles.

Although the circulation of Dutch newspapers has decreased over the years, there were still 3,003,859 newspapers issued in 2016 (NOM, 2017). Scholars divide newspapers into two main categories. The first category refers to quality newspapers which tend to be aligned with the traditional political parties. These newspapers are less inclined to criticise the 'establishment' and aim to appear unbiased. This suggests that they are less likely to promote populist messages. The second category embraces popular newspapers which are quite independent from mainstream political parties. They concentrate their attention on the mass audience and are more likely to criticise the 'established elite'. Hence, they are expected to be more sympathetic to 
populist ideas (Mazzoleni, 2003, p. 8; Rooduijn, 2013, p. 106). The newspapers investigated in this analysis are selected on the basis of this distinction. Furthermore, the selection represents different ideological viewpoints.

Table 2: The selected newspapers

\begin{tabular}{|l|l|l|l|}
\hline & De Telegraaf & De Volkskrant & nrc.next \\
\hline $\begin{array}{l}\text { Type } \\
\begin{array}{l}\text { Political } \\
\text { orientation }\end{array}\end{array}$ & $\begin{array}{l}\text { Popular } \\
\text { Right-wing }\end{array}$ & $\begin{array}{l}\text { Quality } \\
\text { Centre-left }\end{array}$ & $\begin{array}{l}\text { Quality } \\
\text { Left-liberal }\end{array}$ \\
\hline $\mathbf{2 0 1 6}$ & 426,827 & 258,415 & 30,767 \\
\hline
\end{tabular}

Source: author's own elaboration based on NOM (2017)

The selection is presented in Table 2 and includes De Telegraaf, De Volkskrant, and nrc.next. De Telegraaf is the largest Dutch newspaper with a circulation of 426,827 issues in 2016 (NOM, 2017). It is usually perceived as a popular newspaper because it devotes more attention to "sensational articles, sports and gossip" (Akkerman, 2011, p. 934). De Volkskrant is the country's third-largest newspaper and is seen as a quality newspaper with a quite strong political vision (p. 936). Nrc.next is not as widely read as the other two newspapers with a circulation of 30,767 in 2016 . It is a quality newspaper as well with a primary target group of higher educated people in their twenties and thirties. While De Telegraaf is usually classified as right-wing, De Volkskrant has a tendency to lean to the centre-left, and nrc.next can be regarded as left-liberal. These three newspapers provide a comprehensive overview of how the PVV is framed in the media. The choice is made to concentrate on ideologically different newspapers because it is interesting to observe whether this also causes different approaches in the coverage of the PVV.

\subsection{Data collection}

This research concentrates on specific time periods because the period from the PVV's establishment in 2006 until today is too long to study in a qualitative research. The selection of the time periods is instructed by the objective to cover a period in which the PVV is portrayed extensively in the media. Consequently, there is a focus on the weeks surrounding the Dutch parliamentary elections and the European parliamentary elections. Every period is of a two-months length, covering one month before the elections and one month after them. The respective time periods are as follows. The first period is from 22 October until 22 December 2006. The second period is from 9 May until 9 July 2010. The third period is from 22 April until 22 June 2014. Hence, the newspaper articles are collected according to these time periods. This combination of periods generates an overview of the frames in the media in the PVV's founding phase, its immense victory in the 2010 elections, and its loss in the 2014 European Parliament elections. While it might be argued that two months is too short to generate long-term trends for a particular election, the aim of this research is to regard whether there is 
a change in framing over time. Therefore, short time periods across several years are chosen.

The articles from the three newspapers are collected through the use of the LexisNexis database. The search is conducted using the words PVV, Partij voor de Vrijheid, and Wilders as keywords. These keywords are searched in the headlines of the articles because the public interested in political parties is most likely to read articles on the basis of the headline's content.

\section{The analysis: framing the PVV}

The keyword search in the three time periods on LexisNexis yielded a total number of 200 newspaper articles concerning the PVV and its leader Geert Wilders. The search generated 85 articles from De Telegraaf, closely followed by De Volkskrant with 83 articles, and nrc.next contained 32 articles. Similar searches were conducted for the Dutch liberal party, VVD, and the Dutch labour party, $P v d A$, to observe whether this number of articles is high or low in comparison to media coverage of other political parties. The searches yielded 318 articles for the $V V D$ and 270 articles for the $P v d A$. These results show that the coverage of the PVV is not as high as that of the traditional parties but the differences are not of major significance.

Figure 1: Total number of articles 2006-2014

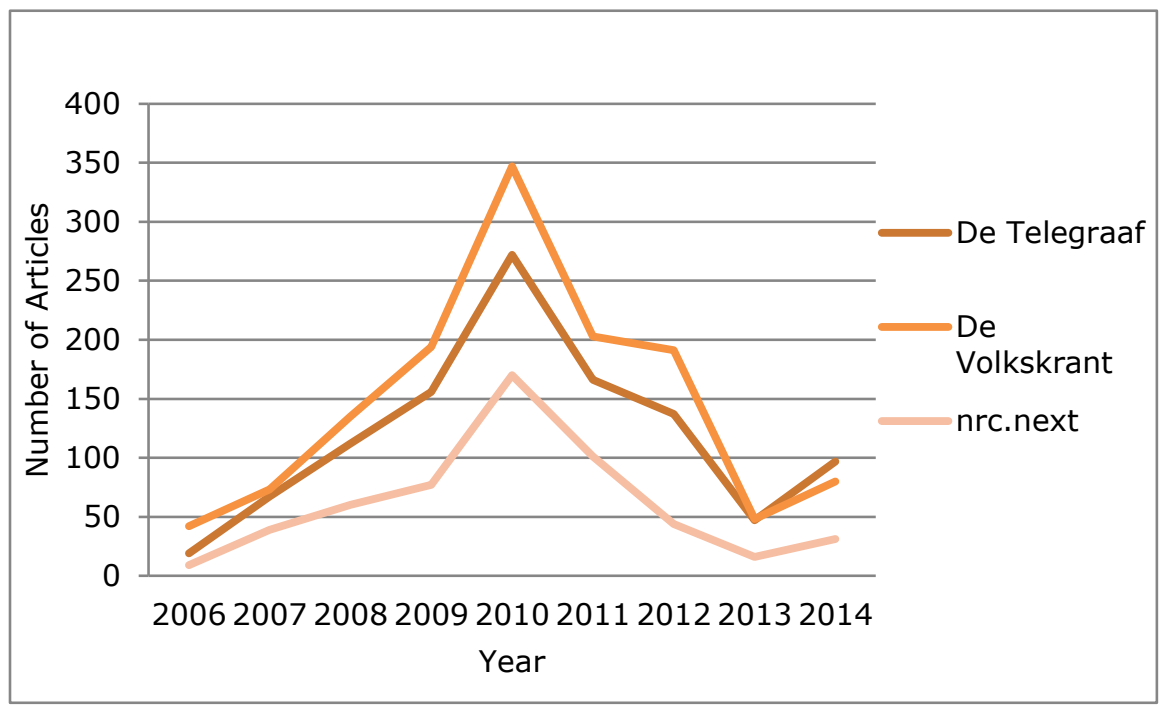

Source: author's own elaboration based on LexisNexis (2017)

Figure 1 presents an overview of the total media coverage by the three newspapers between 1 January 2006 and 31 December 2014. The year 2010 is a peak in the coverage of the PVV in every newspaper with a total of 789 articles. This might be explained by the peculiar nature of the 2010 parliamentary elections and the subsequent cabinet formation. The PVV 
became the third largest party during these elections. The cabinet formation was characterised by the difficulty to reach a majority government. Eventually, a cabinet construction was accepted, a gedoogconstructie, which is only rarely used in the Netherlands. This meant that the PVV became a supporter of the government, though not an official coalition party. Troughs are visible in 2006 (70 articles) and 2013 (111 articles). This shows that in the period after its establishment the $P V V$ did not receive that much attention yet in the media. This might be caused by the idea that the party would not sustain for a long time following the example of the $L P F$.

Figure 2: Total number of articles per time period

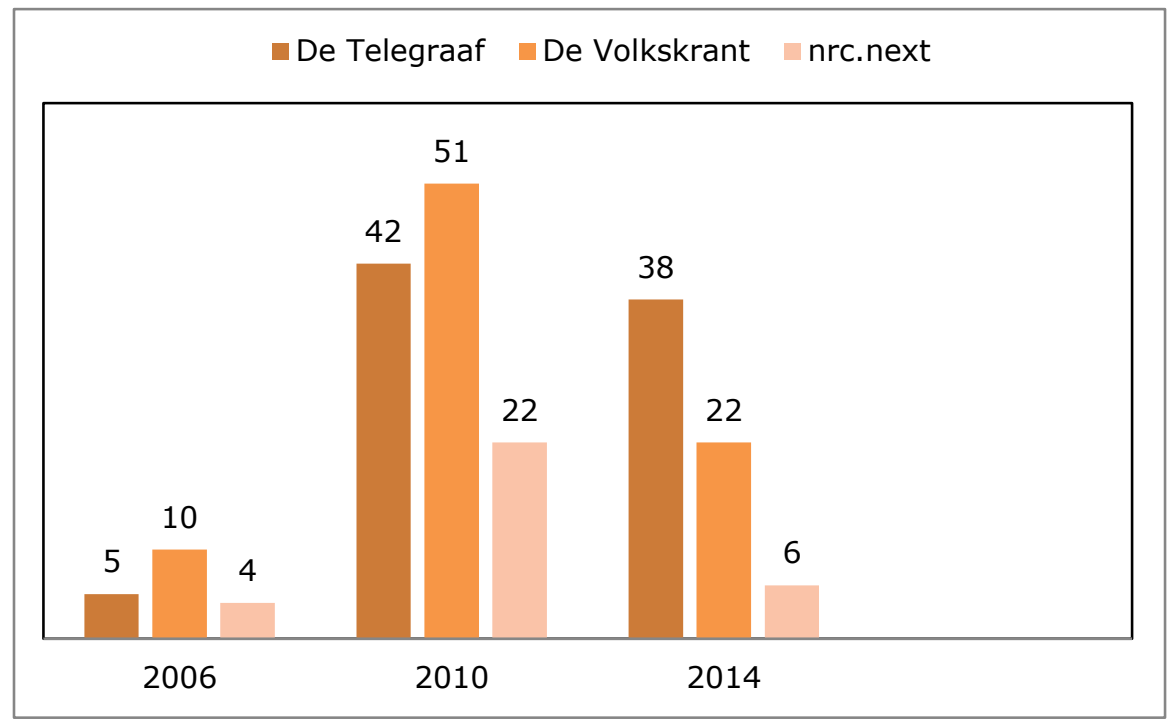

Source: author's own elaboration based on LexisNexis (2017)

Figure 2 introduces the number of articles per newspaper per time period in 2006, 2010, and 2014. It is striking that there are substantial variations between the coverage in the different periods even though all embrace times around elections. The 2006-period demonstrates that the overall interest in the PVV during the elections was still minor at this point. This is remarkable since the PVV received a relatively large share of votes for a party that had just been established. The party won nine seats in parliament and became the fifth largest party. By the time of 2010 this had changed. The overall peak is also visible in the examined period. All newspapers wrote more than five times as many articles concerning the PVV and Wilders than four years earlier. In 2014, De Volkskrant and nrc.next had seemingly lost their interest as their number of published articles decreased by more than half. De Telegraaf is more consistent with a decrease of only four articles compared to 2010.

As a first step in the analysis, the 200 newspaper articles are sorted into different categories to receive a general overview of the subjects they address. Figure 3 presents this categorisation and states the respective 
percentages of articles per category. The largest category consists of the articles containing general information about the PVV (24\%). These feature information about for instance its members, changes within the party, its issue positions, and interviews with Geert Wilders. The second largest category, with a total number of 37 articles $(18,5 \%)$, is concerned with the coverage of conflicts or problems inside the PVV $(8,5 \%)$ and its clashes with external actors $(10 \%)$. It is interesting that per time period, the number of articles in this category increases. This suggests that the longer a political party exists, the more issues it encounters over time. The third largest category is made up of articles about the developments in the formation of a new Dutch cabinet (17\%).

Figure 3: Percentages of articles per category

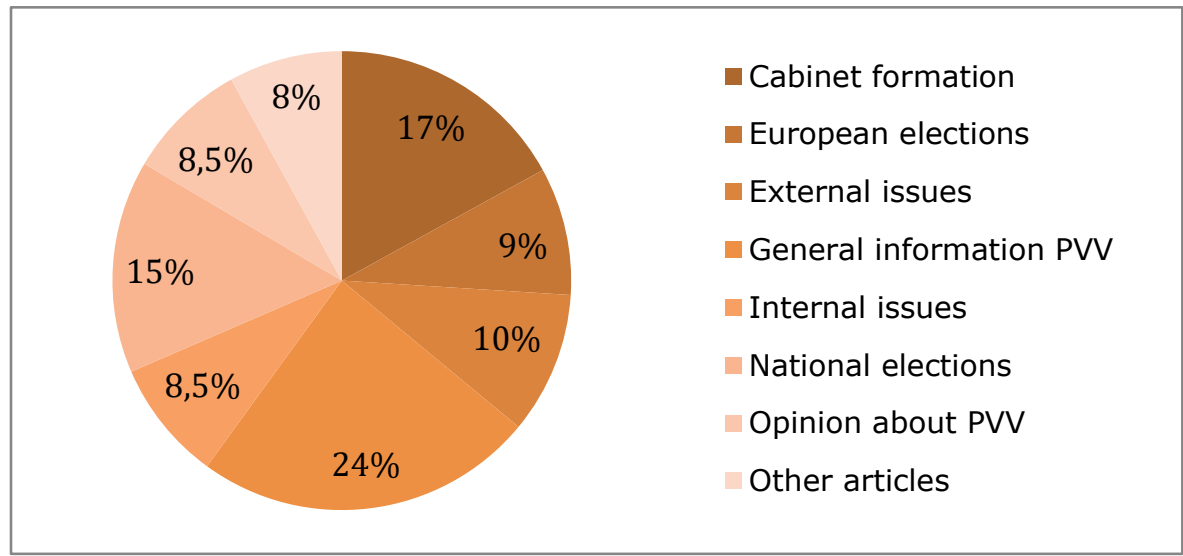

Source: author's own elaboration based on LexisNexis (2017)

All these articles are written in the second time period in 2010, which means that almost $30 \%$ of the articles in 2010 is concerned with the cabinet formation. This is a plausible observation since the chances of the PVV becoming a government party for the next four years were considerable. Although the three time periods were chosen to include national elections and European Parliament elections, their respective categories are only found at a fourth $(15 \%)$ and fifth $(9 \%)$ place. The newspapers reported to a lesser degree on particular opinions about the PVV coming from for instance citizens, other political parties and their leaders, and the foreign press. The last category of 'other articles' (8\%) incorporates articles from a variety of other subjects.

\subsection{The 2006 elections}

As a second step in the analysis, the three time periods are investigated separately. The first time period ranges from 22 October until 22 December 2006. It incorporates the first elections in which the recently established PVV participated.

The articles from De Telegraaf provide general information about the $P V V$ and they cover the national elections. They display an acceptance of the 
PVV as one of the 'victors' of the parliamentary elections. It is acknowledged that it has never before occurred that a party established by a former member of a traditional party is so successful in its first election (Wilders 'beretrots', 2006, November 23). Articles fail to present the party's standpoints and its election program. De Telegraaf does emphasise Wilders' hatred towards Moroccans. One article stipulates that when PVV colleagues were assaulted by young adults, Wilders accused them to be Moroccans even before the police could confirm this (Posterplakkers gemolesteerd, 2006, October 29).

De Telegraaf characterises Wilders as an ex-liberal party member who has developed an aversion to the current party leader Mark Rutte. Wilders' success is explained by the idea that he 'hijacked' a lot of parliamentary seats from the $V V D$. Furthermore, news stories concentrate on Wilders' offensive statements. For instance, "the VVD is too weak and unclear with Mark Rutte in charge" (Wilders juicht, 2006, November 23). Wilders also reproaches Rutte for having "weak knees" when making decisions (Wilders spint garen, 2006, December 15). One article stresses that Wilders believes his party will never be confronted with so-called "LPF-circumstances" which refers to the crumbling of this party soon after its success. This portrays Wilders as an over-confident party leader (Wilders 'beretrots', 2006, November 23). The main problem by which the PVV is conceptualised is the rise of an extreme party with an aversion to the traditional political elite. The articles implicitly contain a negative moral evaluation through their concentration on the negative, offensive statements of Wilders. Hence, an 'anti-establishment party' frame is derived.

Similar to De Telegraaf, De Volkskrant mostly covers general information about the PVV and the national elections. Articles show that the newspaper is astonished by the party's success in its first elections. One article addresses it as a "spectacular victory" and characterises Wilders as one of the large winners moving from one to nine seats (SP wint fors, 2006, November 23). Other articles bring forward that Wilders is "passionately loved" by Dutch citizens (Vermeulen, 2006, November 23), the PVV is the largest newcomer in parliamentary history after the LPF (Ten Hoove \& Van Lieshout, 2006, November 24), and are amazed by the remarkably high percentage of people that voted for Wilders in his birthplace Venlo (De Graaf, 2006, November 24).

Unlike De Telegraaf, De Volkskrant does not emphasise the negative and offensive language Wilders tends to use. Rather, it concerns itself with the introduction of the other party members who will sit next to Wilders in parliament and the party's general points of view. The PVV's success is explained by the citizens' conception that the Netherlands should return to the way it was and their respective aversion to foreigners (Ten Hoove \& Van Lieshout, 2006, November 24; Trommelen, 2006, December 16). The newspaper utilizes a quite neutral evaluation as judgmental language is lacking. It applies an 'amazed-by-success' frame which entails that De Volkskrant is astonished by the party's sudden success. Consequently, it tries to find out what the party wants and who its members are.

Nrc.next, like De Volkskrant, shows astonishment in its coverage of the PVV's victory in the parliamentary elections by stating "who would have thought that?" (Van den Berg \& Valk, 2006, November 24). The newspaper states that people vote for the party because they want to protect the 
Netherlands. Articles also provide information about its standpoints and the party members. Other coverage is rather negative in its tone. One news story blames Wilders that he does not bother to defend his position with specific arguments and only uses harsh 'one-liners' in debates (Duursma, 2006, October 24). Another article presents Wilders as being 'too scared' to appear in public together with the traditional political parties. Wilders had apparently cancelled his participation in a TV programme due to the presence of D66leader Pechtold (Brandt Corstius, 2006, November 20). Consequently, it can be derived that nrc.next applies a combination of both the 'amazed-bysuccess' and the 'anti-establishment party' frames. Its overall attitude towards the PVV and Wilders is negative.

Table 3: Media frames in period 1

\begin{tabular}{|c|c|c|c|}
\hline & De Telegraaf & De Volkskrant & nrc.next \\
\hline Media frame & $\begin{array}{l}\text { Anti- } \\
\text { establishment } \\
\text { party }\end{array}$ & Amazed-by-success & $\begin{array}{l}\text { Anti- } \\
\text { establishment } \\
\text { party }\end{array}$ \\
\hline $\begin{array}{l}\text { Problem } \\
\text { definition }\end{array}$ & $\begin{array}{l}\text { The aversion } \\
\text { towards the } \\
\text { traditional } \\
\text { political elite }\end{array}$ & $\begin{array}{l}\text { Astonishment of } \\
\text { Wilders' success } \\
\text { in the election } \\
\& \\
\text { The } \\
\text { characterisation } \\
\text { of Wilders and his } \\
\text { party }\end{array}$ & $\begin{array}{l}\text { Astonishment of } \\
\text { Wilders' success in } \\
\text { the election } \\
\& \\
\text { Aversion towards } \\
\text { the traditional } \\
\text { political elite }\end{array}$ \\
\hline $\begin{array}{l}\text { Causal } \\
\text { interpretation }\end{array}$ & $\begin{array}{l}P V V \text { attracts a } \\
\text { lot of former } \\
V V D \text {-voters }\end{array}$ & $\begin{array}{l}\text { Enmity against } \\
\text { foreigners, } \\
\text { especially with a } \\
\text { Muslim } \\
\text { background }\end{array}$ & $\begin{array}{l}\text { Protectionism of the } \\
\text { Netherlands }\end{array}$ \\
\hline $\begin{array}{l}\text { Moral } \\
\text { evaluation }\end{array}$ & Negative & Neutral & Negative \\
\hline
\end{tabular}

The overview provided by Table 3 shows that De Telegraaf and nrc.next frame the PVV in a negative manner while De Volkskrant tends to be overly neutral. De Telegraaf primarily depicts the party and Wilders as extreme antiestablishment figures. Nrc.next presents a similar trend but is more moderate. This newspaper also shows some sense of surprise of the party's success which is De Volkskrant's predominant depiction in its coverage.

\subsection{The 2010 elections}

The second period under investigation ranges from 9 May until 9 July 2010 and covers the 2010 elections. In the month before the elections of June $9^{\text {th }}$, De Telegraaf concentrates on the issues the PVV encounters. Several articles address the "mutiny" that commenced within the party. PVV-member Hero Brinkman criticises Wilders and blames the party to be undemocratic (Muiterij in PVV, 2010, May 11). Other news stories focus on the conflict between Wilders and PvdA-leader Job Cohen. Cohen called the party a "danger to the 
rule of law" on which Wilders reacted that "the PvdA itself is a danger to the rule of law" (PvdA zélf gevaar, 2010, June 4). In another heated debate with Cohen, Wilders declared that the party's policies bring the Netherlands to the "edge of the abyss" (Wilders bijt van zich af, 2010, June 8). Moreover, the public broadcaster $K R O$ called upon its members not to vote for the PVV and in a "sick" broadcast from the programme Zembla Wilders was compared to Hitler (Oproep KRO valt slecht, 2010, May 26; Oplossing Zembla, 2010, May 31).

After the elections, the attention shifted to the cabinet formation. De Telegraaf emphasises that Wilders wants to govern, no matter what. The articles demonstrate that he adopts a more moderate tone and he is willing to relinquish some of his standpoints (PVV wil meeregeren, 2010, June 4; Rutte zint op rechts, 2010, June 11). However, the newspaper brings forward that the PVV might be too unstable to govern (Rutte verlangt uitleg, 2010, June 12). Furthermore, there originates a large aversion to this idea of governing from the established political elite. In particular, $C D A$-members put up a lot of resistance (Naaktgeboren, 2010, June 14). When the formation of the cabinet $V V D-C D A-P V V$ failed, the news stories implicitly suggested that the PVV was deliberately put out of action and CDA is mainly to blame for this (Buitenspel zet PVV op winst, 2010, June 28). A 'conflict' frame is recognisable since a proportionally high number of the articles concentrate on internal and external issues facing the PVV. Moreover, a 'change in status quo' frame is evident as the rise of the PVV implies that the governments consisting of the traditional political parties cannot be taken for granted anymore. Throughout the articles, a quite neutral approach is taken.

Unlike De Telegraaf, De Volkskrant does not concentrate that much on conflicts concerning the PVV in the period before the elections. Instead, its articles present the party in a bad light. News stories stress that Wilders has found a "catch-all scapegoat" in the religion of Islam (Sommer, 2010, May 25). PvdA-leader Cohen is placed in a victim role with the declaration that Wilders' "common attacks" on him are still prominent (Du Pré, 2010, May 26). The possible collaboration with Wilders in a new government is also addressed. An article indicates that a government including the PVV is "undesirable". It will cause political risks and harm the Dutch image abroad (Geen PVV-coalitie, 2010, June 5).

De Volkskrant extensively addresses the cabinet formation and the elections with 30 out of 51 articles. It emphasises that the need of a "Wailing Wall" under the population accounts for the PVV's success (Marbe, 2010, June 11). Unlike De Telegraaf, it takes a rather negative viewpoint towards the party concerning the coalition talks. Articles mention that the PVV desperately wants to be a part of the new government. However, chances for this to be realised are only minor and the other political parties are not eager to collaborate (Meerhof, 2010, June 10; Marbe, 2010, June 11). CDA in particular puts Wilders in a difficult position. Articles state that governing with the PVV entails negative consequences for CDA (Hoedeman \& Meerhof, 2010, June 12). Moreover, $C D A$-leader Verhagen dominated the formation talks by his continuous absence (Doorduyn \& Meerhof, 2010, June 16). De Volkskrant also blames CDA for the possibility of Wilders ending up in the opposition instead of in government (Meijer, 2010, June 19). Consequently, an 'antiestablishment party' frame is derived. The newspaper stipulates that the PVV remains a party that does not belong to the status quo as evidenced by the 
continuous coverage on the aversion against the party from the traditional political elite. The articles contain a negative moral evaluation.

Before the elections, nrc.next mainly published articles with a negative attitude towards the $P V V$. The internal conflict with Hero Brinkman is presented by the statement "the unity has been broken permanently" (Rijlaarsdam, 2010, May 25). Wilders' argument that non-western immigrants cost the government a lot of money is addressed as well. The news story stresses that a recent rapport demonstrates that the differences in costs with the 'allochtone' population are in fact not that substantial (Garschagen \& Vriesinga, 2010, May 21). Articles also cover the evocations by public broadcaster $K R O$ and Wilders' brother not to vote for the PVV ('stemadvies' van KRO, 2010, May 26; Vriesema, 2010, May 28).

The coverage on the election results starts with the comment that nrc.next was not very welcome during the election evening of the PVV. A centre-right cabinet $V V D-C D A-P V V$ is rather unlikely and the traditional parties do probably not want to collaborate with Wilders (Rijlaarsdam \& Staal, 2010, June 10). This thought is shared by several other articles. The party's success in Wilders home-province Limburg is explained by the idea that Wilders gives the average citizen a voice (Ajarai \& Vasterman, 2010, June 11). An opinion piece outlines that a coalition with Wilders entails negative consequences for the Netherlands in the EU (Brinkhorst, 2010, June 16). Another piece states that when the Dutch football team loses its next match in the World Championship, its reputation will deteriorate in a similar manner as what has already happened to 'our' political situation (Kok, 2010, July 7). Similar to De Volkskrant, an 'anti-establishment party' frame is derived from the nrc.next articles. The newspaper concentrates on the idea that even though the PVV enjoys successes, it remains distinctive and it might be better if Dutch citizens do not vote for it.

Table 4: Media frames in period 2

\begin{tabular}{|c|c|c|c|}
\hline & De Telegraaf & De Volkskrant & nrc.next \\
\hline Media frame & $\begin{array}{l}\text { Conflict } \\
\& \\
\text { Change-in-status- } \\
\text { quo }\end{array}$ & $\begin{array}{l}\text { Anti- } \\
\text { establishment } \\
\text { party }\end{array}$ & $\begin{array}{l}\text { Anti- } \\
\text { establishment } \\
\text { party }\end{array}$ \\
\hline $\begin{array}{l}\text { Problem } \\
\text { definition }\end{array}$ & $\begin{array}{l}\text { Internal and } \\
\text { external problems } \\
\text { facing the } P V V \\
\text { \& } \\
\text { Change in the } \\
\text { status-quo } \\
\text { concerning } \\
\text { government } \\
\text { coalitions }\end{array}$ & $\begin{array}{l}\text { The 'undesirable' } \\
\text { chance of the } \\
P V V \text { taking part } \\
\text { in the new } \\
\text { government } \\
\text { coalition }\end{array}$ & $\begin{array}{l}\text { An anti- } \\
\text { establishment } \\
\text { party that 'we' } \\
\text { should not vote } \\
\text { for }\end{array}$ \\
\hline $\begin{array}{l}\text { Causal } \\
\text { interpretation }\end{array}$ & $\begin{array}{l}\text { The established } \\
\text { elite's aversion } \\
\text { against the PVV }\end{array}$ & $\begin{array}{l}\text { Realisation } \\
\text { complaints Dutch } \\
\text { population }\end{array}$ & $\begin{array}{l}\text { Wilders gives the } \\
\text { population a } \\
\text { voice }\end{array}$ \\
\hline $\begin{array}{l}\text { Moral } \\
\text { evaluation }\end{array}$ & Neutral & Negative & Negative \\
\hline
\end{tabular}


Table 4 illustrates that the two quality newspapers frame the $P V V$ in a similar manner with an 'anti-establishment party' frame incorporating a negative moral evaluation. De Telegraaf concentrates on the internal and external issues of the PVV and presents the change in the status quo concerning the Dutch cabinet formation. Unlike De Volkskrant and nrc.next, the newspaper's coverage contains neutral language.

\subsection{The 2014 elections}

The third period incorporates the 2014 European Parliament elections and ranges from 22 April until 22 June 2014. The 'conflict' frame remains in De Telegraaf's coverage since it focuses a lot on the issues the PVV encounters. Several articles suggest that the party is crumbling. The departure of some members is addressed by "members are looking for an exit" (Assistent Wilders, 2014, April 24), the "fiasco in the PVV" (PVV moet inpakken, 2014, May 6), and "the dismantling of the PVV" (PVV oppositie, 2014, May 6). The external issue with Saudi Arabia is covered extensively as well. One of the many "provocative actions" against Islam by the party caused the country to respond by imposing a commercial boycott on Dutch entrepreneurs (Wilders, 2014, May 22).

A lot of attention is devoted to the European elections. Before the elections, De Telegraaf condemns Wilders' search for collaboration with "extreme-right" and "anti-Semitic" parties such as Front National and FPÖ (In zee met verkeerden, 2014, May 7). Articles claim that this action is a part of the current "radicalisation" of the PVV. Wilders is prepared to do anything for a victory in the elections (Wilders, 2014, May 8). Articles also emphasise the party's hatred of Moroccans and the other parties' negative opinion of the PVV (Cultuur Marokkanen minderwaardig, 2014, May 14; Flirt PVV, 2014, May 10). Once the election results were published, the news stories adopt a particularly happy tone to address the PVV's loss. The party is confronted with a "rude awakening" by the loss of a quarter of its voters. One article speaks of a "degradation of the PVV" that is widely covered all over Europe (Nederlaag Wilders, 2014, May 25). Another news story stresses that apparently voters cannot "appreciate" Wilders' "flirt with extreme parties" or they are just "too lazy to vote" (Ongeloof bij PVV, 2014, May 23). It is further stated that voters are developing an aversion to Wilders due to his more "radical direction" (Almere wendt zich af, 2014, May 27). De Telegraaf is thus negative about the PVV and sometimes uses judgmental language. The electoral loss is mainly caused by Wilders' own actions as party leader and his changed points of view. A combination of a 'conflict' frame and a 'radical right party' frame is derived. The newspaper concentrates on the issues that the party continuously encounters and the radicalisation that occurs within the party.

De Volkskrant also covers some issues the party is confronted with. Its articles speak of an "exodus at the PVV" concerning both its employees and supporters. This is caused by Wilders' controversial pronunciations regarding Moroccans (Hoedeman \& Meijer, 2014, April 23). Another story declares that these pronunciations undermine the Dutch reputation and its economic interests (Sondaal, 2014, May 20). The withdrawal of Lucas Hartong from the candidate list for the European elections is introduced here as well. The presented reason for this is that he does not want to collaborate with "neo-Nazi's and that kind of people" implying Front National and FPÖ (Giesen \& Heijmans, 2014, April 24). The newspaper condemns Wilders' connection 
with these extreme European parties that carry out anti-Semitic ideas. An article asks whether Wilders is again alienating former friends, namely Israel. It continues by stressing that the PVV is changing its direction to obtain European power and it has become a "radical-right populist party" (Hoedeman, 2014, May 9). Prime Minister Rutte calls Wilders' collaboration with Front National and FPÖ "unwise" (Wagendorp, 2014, May 10).

After the European election results were published, De Volkskrant addresses the PVV's loss by stating that an "anti-Brussels outbreak has failed to appear" (Dreun voor PVV, 2014, May 23). It describes the general confusion that exists among the party's members of how this could happen (Korteweg, 2014, May 23). Even though it does so in a less extreme manner as De Telegraaf, De Volkskrant also adopts a 'radical right party' frame. It devotes a lot of attention to the changing direction of the party and the increasingly extreme pronunciations and actions of Wilders. The moral evaluation is thus also negative.

Unlike the other two newspapers, nrc.next utilizes neutral language throughout the coverage. Its articles concentrate on the internal issue that exists with Martin Bosma. Wilders has successfully prevented Bosma's controversial book about apartheid from being published. This book could have had disastrous consequences for the PVV's performance during the European elections (Meeus, 2014, May 21). Another news story presents that Wilders distances himself from Jean-Marie Le Pen's pronunciation about the Ebola virus being a solution for the migrant problems (Wilders distantieert, 2014, May 22). The other articles discuss some general information about the PVV in the European elections. Nrc.next addresses the ins and outs of the party in a non-judgmental manner. Therefore, an 'established party' frame is derived in which the $P V V$ is approached as any other political party.

Table 5: Media frames in period 3

\begin{tabular}{|c|c|c|c|}
\hline & De Telegraaf & De Volkskrant & nrc.next \\
\hline Media frame & Conflict & Radical right party & $\begin{array}{l}\text { Established } \\
\text { party }\end{array}$ \\
\hline $\begin{array}{l}\text { Problem } \\
\text { definition }\end{array}$ & $\begin{array}{l}\text { A radicalising } \\
\text { right-wing party } \\
\text { confronted with } \\
\text { considerable } \\
\text { internal and } \\
\text { external issues }\end{array}$ & $\begin{array}{l}\text { A radicalising } \\
\text { right-wing party } \\
\text { that encounters } \\
\text { internal issues }\end{array}$ & $\begin{array}{l}\text { Ins and outs of } \\
\text { the } P V V\end{array}$ \\
\hline $\begin{array}{l}\text { Causal } \\
\text { interpretation }\end{array}$ & $\begin{array}{l}\text { Wilders' own } \\
\text { actions and } \\
\text { pronunciations }\end{array}$ & $\begin{array}{l}\text { Wilders' own } \\
\text { actions and } \\
\text { pronunciations }\end{array}$ & 1 \\
\hline $\begin{array}{l}\text { Moral } \\
\text { evaluation }\end{array}$ & Negative & Negative & Neutral \\
\hline
\end{tabular}

Table 5 exhibits that De Telegraaf and De Volkskrant frame the PVV as a 'radical right party' around the European elections. Both stress that the party is radicalising. De Telegraaf also continues to adopt a 'conflict' frame in its articles. Nrc.next takes a completely different approach with an 'established 
party' frame through which it depicts the PVV in a non-judgmental manner as any other political party.

\subsection{Change in media frames over time}

The analysis demonstrates that the newspaper articles address a substantive amount of different subjects. The successes and failures of the PVV in the different elections are covered. Furthermore, attention is devoted to Wilders' controversial pronunciations with a quite radical tone. The internal and external issues that the party is confronted with are highlighted as well. In addition, there exists a consensus among the three newspapers concerning the reasons behind the success and failure of the PVV. Their articles bring forward that the party's success can be explained by the fact that it gives citizens a voice again and aims at protecting the Netherlands from foreigners, which is something that the traditional political elite allegedly fails to do. Moreover, the party's failures are held to be mainly caused by Wilders' own pronunciations and undertaken actions.

It is evident that ever since its establishment in 2006, the PVV has continuously been portrayed as distinctive. Articles show that the party criticises the traditional political elite and vice versa, but also that it has a different party structure and other points of view. Therefore, 'antiestablishment party' frames are derived in 2006 and 2010. It is recognised that the media portrayal has become increasingly negative over time. De Volkskrant and nrc.next are still surprised and amazed by the PVV's unexpected success in 2006, but replace this tone by 'anti-establishment' depictions in 2010. By this time, De Telegraaf's articles also concentrate on the conflicts the party encounters and address how the PVV is changing the status quo in Dutch politics. This focus on conflicts is still evident in 2014 but by now the party is perceived as 'radical' by both De Telegraaf and De Volkskrant. These growing extreme depictions have not been identified before by academic work. Furthermore, the observations imply that the Dutch newspapers contribute to a negative, 'anti-establishment' environment for the $P V V$. However, this does not seem to influence voting behaviour as extensively as the works of for instance Mazzoleni (2003) and Pels (2011) suggest since the party still managed to become the second largest party in the 2017 elections.

Two important notes have to be made here. First, even though the newspapers are increasingly negative, this does not go as far as to 'demonise' Wilders or the PVV. Bosman \& d'Haenens (2008) find that this did happen to Pim Fortuyn in 2002 as De Telegraaf and De Volkskrant associated him with Nazis and fascism (p. 746). This observation strengthens Rooduijn's (2013) argument that newspapers have become more open to populism over time. Second, the analysis shows that political orientation does not visibly shape the newspapers' coverage. In addition, the popular newspaper De Telegraaf is not more sympathetic towards the PVV than the two quality newspapers. On the contrary, in the case of a negative moral evaluation, it portrays the party in the most negative manner of the three newspapers. This finding is in accordance with that of Akkerman (2011). Her study concludes that popular newspapers are not necessarily more sympathetic to populist ideas than quality newspapers. 


\section{Conclusion}

This study explored the relationship between the media and populism to better understand the role of the media in national politics. Previous literature concentrated on defining populism and finding explanations for its rise. The literature review showed that the media play an important part in the success and/or failure of populist parties. However, there is a lack of a systematic investigation of the link between populist parties and the research on mediaeffects in the academic work. Therefore, a newspaper analysis of the PVV in the Netherlands was conducted. The concept 'framing' was used as a helpful tool to make sense of the newspaper articles' content. Media frames were derived on the basis of the elements problem definition, causal interpretation, and moral evaluation.

The analysis showed that the newspapers mainly depict the PVV in a negative manner, despite their different political orientations. It further demonstrated that the media frames have changed over time. In 2006, the newspapers were still amazed by the party's success in its first elections. An anti-establishment sentiment was also already visible at this point in time. By 2010, this anti-establishment party frame was consolidated. Attention was devoted to the PVV's conflicts as well and a changing status quo in Dutch politics was remarked. In 2014, the party was mainly portrayed as a radical right party. The PVV is thus covered as increasingly extreme over time, even though some deviations were evident. Hence, the analysis implied that the newspapers generate a negative environment for the party in Dutch politics.

This research adds to the current academic debate concerning the role of the media in the rise and/or failure of populist parties. It bridged the gap between the work that traces the relationship between the media and populism and the media-effects literature. It also provided a new angle from which to research the $P V V$ in the Netherlands. It found that Dutch newspapers have become more open to populist ideas. Moreover, the expectation that popular newspapers are more likely than quality newspapers to promote populist ideas was refuted. The analysis showed that both types of newspapers are rather negative towards the populist parties.

Since a newspaper analysis is unable to provide a holistic understanding of how the media shape the public's perceptions towards populist parties, future research should concentrate on other forms of media as well. Television, radio, and social media might expose the public to considerably different information about these parties. It is also necessary to remark that this research only had a limited choice of cases. It would be interesting to reproduce the analysis for other Dutch newspapers. Another possibility would be to extend the time frame to other time periods such as the parliamentary elections in 2017. Furthermore, further research could undertake a cross-national study to compare media frames in different countries and for different populist parties. 